\title{
Air pollution in a microclimate; the impact of different green barriers on the dispersion
}

\author{
Mohammad Taleghani ${ }^{1 *}$, Andrew Clark ${ }^{1}$, William Swan ${ }^{1}$, Arash Mohegh ${ }^{2}$ \\ ${ }^{1}$ University of Salford, Manchester, UK \\ ${ }^{2}$ George Washington University, Washington, DC, USA
}

\begin{abstract}
This paper studies the impact of different green barriers on the dispersion of air pollution in a neighbourhood. The study was performed with reference to air quality conditions in Manchester, UK. Manchester experiences a high level of $\mathrm{NO}_{2}$. Measured results showed that the average annual concentration level in $\mathbf{2 0 1 8}$ was very close to the limit defined by European Union legislation. Maximum and minimum $\mathrm{NO}_{2}$ concentrations occurred during the winter and summer, respectively. Simulations of the dispersion of air pollution in a hypothetical neighbourhood showed that $\mathrm{NO}_{2}$ level was decreased by the increase of air temperature during the simulated day. In four perturbation scenarios, hedges and trees with different heights were added to the neighbourhood as green barriers. Hedges increased the pollution level near the street at the pedestrian level as a result of the reduced wind speed. The simulations demonstrated that using the trees facilitated the dispersion of pollution.
\end{abstract}

\section{Keywords}

Air pollution, dispersion, microclimate, green barriers

\section{Introduction}

This research explores a simulation of the use of green barriers on air pollution within an urban environment. Policy makers see the green infrastructure has a role to improve pollution related health outcomes in cities. This can lead to a possible view that green infrastructure is universally beneficial no matter how applied. These simulations explore the impact of differing green barriers within a simulated microclimate to explore how the dispersion of pollution is affected in a localised area. This has been done to better understand possible issues for green infrastructure strategies for urban environments.

\footnotetext{
1* Corresponding author: Mohammad Taleghani (m.taleghani@salford.ac.uk) Co-authors' contact: Andrew Clark (a.p.clark@salford.ac.uk); William Swan (w.c.swan@salford.ac.uk); Arash Mohegh (mohegh@email.gwu.edu)
} 
There is a growing concern about air pollution in UK since the great smog of London in December 1952 that led to thousands of deaths [1]. This event raised public awareness about air quality, and led to the Clean Air Act in 1956 [2] which introduced measures to reduce air pollution in UK. Since 1990, most air quality pollutants have decreased due to the tighter standards for power generation and vehicle fuels, and better vehicle engine designs [3]. Among different types of pollution, exposure to nitrogen dioxide $\left(\mathrm{NO}_{2}\right)$ and particulate matter (PM) are still the main causes of pollution related mortality in the UK. The committee on the Medical Effects of Air Pollutants estimated that 28,000 to 36,000 annual premature deaths in UK are related to particulate matter, which is one type of air pollution [4]. Another study by the Royal College of Physicians estimates up to 50,000 deaths from the combination of $\mathrm{PM}$ and $\mathrm{NO}_{2}$ [5]. Achakulwisut et al. [6] also report that $13 \%$ of all paediatric asthma cases in cities are attributable to $\mathrm{NO}_{2}$.

The Air Quality and Clean Air for Europe Directive (2008/50/EC) established thresholds for the protection of human health in EU countries, which are implemented by all European member states. This directive states: "The EU has set two limit values for nitrogen dioxide $\left(\mathrm{NO}_{2}\right)$ for the protection of human health: the $\mathrm{NO}_{2}$ hourly mean value may not exceed 200 micrograms per cubic metre $\left(\mu \mathrm{g} / \mathrm{m}^{3}\right)$ more than 18 times in a year and the $\mathrm{NO}_{2}$ annual mean value may not exceed 40 micrograms per cubic metre $\left(\mu \mathrm{g} / \mathrm{m}^{3}\right)^{\prime \prime}$ [7]. Apart from human health, $\mathrm{NO}_{2}$ can also affect vegetation [8-10]. $\mathrm{NO}_{2}$ is both a primary and secondary pollutant:

a) It is produced when fossil fuels are burned for transportation, power generation, and heating. The main source of $\mathrm{NO}_{2}$ in UK cities is road transport [3].

b) It forms from chemical reactions that take place in the atmosphere following the emission of nitric oxide ( $\mathrm{NOx}$ ). Much atmospheric $\mathrm{NO}_{2}$ results from secondary transformation of NOx.

Heat mitigation strategies can reduce air pollution indirectly [11-13]. Akbari et al., [14] identified in a study of 100 cities in the US that vegetation and high albedo materials can reduce urban smog (the term smog is the combination of smoke and fog). They showed that by cooling city centres, energy demand for air-conditioned buildings will be reduced. This leads to less energy production by powerplants that mostly rely on fossil fuels. It should be said that lower ambient air temperatures slow the chemical reactions that generate secondary pollutants such as ozone and nitrogen dioxide.

Street canyon design can also affect the dispersion of pollution in cities [15]. While parallel wind within canyons can enhance the dispersion of pollution, Oke et al., [16] argued that perpendicular wind can create a vortex within the canyon. The vortex can make an opposite wind near the ground which may circulate pollution within the canyon. It should be noted that other factors like the flow of the transportation can affect the dispersion in a canyon.

Seasonal differences can also affect the dispersion. During the summer time, air pollution is less problematic than winter time. In cold periods, the urban climate is more stable and the polluted near surface air does not rise up like summer time. This phenomenon, which is called temperature inversion, can trap air pollution within cities [17]. Qiu et al., [18] shows 
that there is a direct relationship between cold episodes and chronic obstructive pulmonary disease in Hong Kong. Furthermore, Guo et al. [19] found that air pollution-related mortality decreases during rainy seasons in Thailand.

Several studies have shown how vegetation can abate air pollution in different pathways [20-22]. Abhijit et al. [23] undertook a major systematic review of previous studies in this field. They compared the impact of trees, hedges, green walls, and green roofs on air quality in open roads and street canyons. They concluded that in general green elements can improve urban air quality; however, high-level trees may reduce the circulation of air within a canyon and trap the air pollution close to ground level. Their study showed that green barriers should be implemented with caution. Abbass et al. [24] studied the impact of five common indoor plants on ozone removal observing that the plants have different deposition velocities (Golden Pothos with $5.6 \mathrm{~m} / \mathrm{h}$, and Ficus with just $0.5 \mathrm{~m} / \mathrm{h}$ ). In another study in Portland, Oregon, Ramasubramanian et al., [25] showed that green roofs not only reduce outdoor air pollution, but that they also filter near-building air pollutants entering the ventilation systems. In a study on the impact of roadside trees on fine particles ( $\left.\mathrm{PM}_{2.5}\right)$ in Istanbul, Turkey, Ozdemir [26] showed that Mediterranean Cypress trees reduced the air pollution to urban background level.

It should be noted that public perception considers green strategies as the best solution for the abatement of air pollution. However, several studies have shown that inappropriate design of green (or bare) barriers in urban canyons could increase the concentration of air pollution at ground level, for example beneath tree canopies where air circulation becomes restricted. This challenge will be addressed in this paper. Manchester is one of the most populated cities in UK and experiences high concentrations of $\mathrm{NO}_{2}$ [27]. This paper first evaluates the temporal variations of $\mathrm{NO}_{2}$ in Manchester in 2018. Afterwards, a parametric analysis is performed on a hypothetical neighbourhood through computational fluid dynamic simulations. Finally, the impact of different green barriers on the abatement of air pollution in the neighbourhood is addressed.

\section{Methods}

\subsection{Air quality measurement in Manchester}

Air quality is being recorded in UK by local authorities on behalf of the Department for Environment, Food \& Rural Affairs [28]. Around 300 monitoring sites record different pollutant types. Air temperature and $\mathrm{NO}_{2}$ concentration data for this paper were acquired from the monitoring site of Manchester Piccadilly Gardens. This station is located in a populated and commercial area in the city centre of Manchester. Hourly data were retrieved for the whole 2018. 


\subsection{Micrometeorological model}

This paper employed ENVI-met v4.4 as a microclimatological model [29]. ENVI-met was initially developed in 1990s to simulate the outdoor thermal conditions in an urban microclimate. There is a body of literature on outdoor thermal comfort studies that rely on the use of ENVI-met [30-33]. The architecture of ENVI-met consists of four models:

- Atmospheric, such as air temperature and humidity, wind field, turbulence, radiative fluxes, and pollutant dispersion;

- Soil model, which includes surface and soil temperature, soil water content, vegetation water supply, and water bodies and ponds;

- Vegetation model, which supports 3D plant geometry, foliage temperature, and exchange processes with the environment; and

- Built environment and indoor building systems; which can fully simulate the $3 d$ geometry of buildings, details on facades, and indoor energy use [29].

Recent developments of the model allow the users to replicate the release, dispersion and deposition of pollutants of particles, and active and passive gases. Sedimentation and deposition of pollutants on urban surfaces and vegetation are considered in the model. Furthermore, the photochemical reactions between the gases are taken into account [29]. ENVI-met uses a standard advection-diffusion equation for the dispersion of gaseous or particulate components [34]:

$\frac{\partial u}{\partial t}+A \frac{\partial u}{\partial x}+B \frac{\partial u}{\partial y}+C \frac{\partial u}{\partial z}=\alpha\left(\frac{\partial^{2} u}{\partial x^{2}}+\frac{\partial^{2} u}{\partial y^{2}}+\frac{\partial^{2} u}{\partial z^{2}}\right)$

where $A, B$, and $C$ in the equation are the velocity components of the fluid in $x, y$, and $z$ directions, respectively. $\alpha$ is the coefficient of diffusivity which is calculated via Equation 2:

$\alpha=C_{T} / \rho D_{\rho}$

where $C_{T}$ is thermal conductivity $(W /(m \cdot K)), \rho$ is pressure $(P a)$, and $D_{\rho}$ is specific heat of the fluid at constant pressure $(\mathrm{J} /(\mathrm{K} \mathrm{kg}))$.

\subsection{The simulation domain and the scenarios}

In this paper, the impacts of different green strategies on the dispersion of air pollution are studied. The control scenario has no vegetation within the neighbourhood as a barrier. Four green scenarios were then added to the neighbourhood. These scenarios are shown in Figure 1-a. As green barriers; two scenarios use hedges with the height of $2 \mathrm{~m}$ and $4 \mathrm{~m}$ (called $\mathrm{H} 2$ and $\mathrm{H} 4$ scenarios, respectively), followed by two other scenarios using trees with the height of $10 \mathrm{~m}$ and $20 \mathrm{~m}$ (T10 and T20 scenarios, respectively). In the T10 and T20 the lower $1 \mathrm{~m}$ and $2 \mathrm{~m}$ of the trees respectively are bare trunks with no branches.

The neighbourhood is designed in a grid shape to be as simple as possible. Grid urban shape in a large scale is very common in North American cities (e.g. San Francisco, New York City, and Vancouver). Manchester is developed with a mixture of different urban shapes 
including grids. See Appendix 1 for two examples of grid shape neighbourhoods in Manchester.

Figure 1-b shows the plan of the simulation domain. The designed neighbourhood is $100 \mathrm{~m} x$ $100 \mathrm{~m} \times 30 \mathrm{~m}$ (length, width and height), with nine identical buildings with $10 \mathrm{~m} \times 10 \mathrm{~m} \times 10 \mathrm{~m}$ (length, width and height). The ground surface of the neighbourhood is covered with asphalt, the buildings' façades use brick, and the roofs are covered with tiles. A street is located at the left side of the neighbourhood, and the prevailing wind $(2.5 \mathrm{~m} / \mathrm{s})$ is from west to east. A constant $\mathrm{NO}_{2}$ emission of $20 \mu \mathrm{g} / \mathrm{m}^{2}$ is assumed for the street, at a height of $0.5 \mathrm{~m}$. Our aim of setting this constant $\mathrm{NO}_{2}$ emission was to study the impact of temperature fluctuation on pollution dispersion during the day. Five receptor points (R1 to R5) are set to compare the pollution dispersion within the neighbourhood under different scenarios. Figure 1-c shows the 3D view of the neighbourhood with $20 \mathrm{~m}$ trees (T20 Scenario).

a)

$100 \mathrm{~m}$

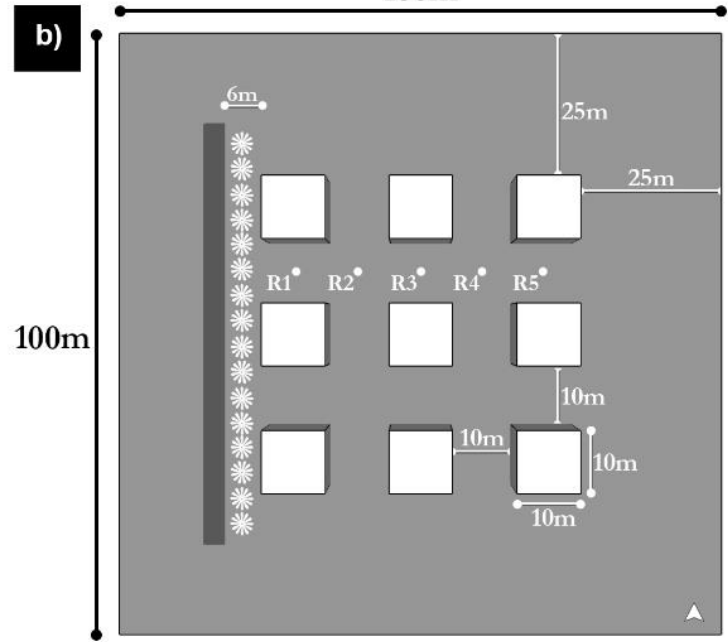

c)

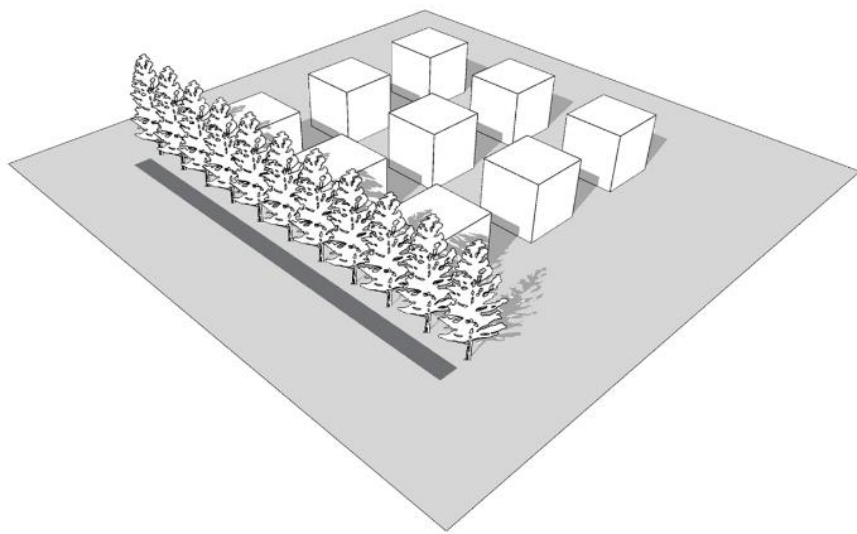

Figure 1: a) Four green barriers used in the perturbation scenarios; b) the plan of the simulation domain; c) the $3 \mathrm{D}$ view of the $\mathrm{T} 20$ scenario showing $20 \mathrm{~m}$ trees between the street and the buildings. 
Manchester is located in the north west of England $\left(53.48^{\circ} \mathrm{N}, 2.24^{\circ} \mathrm{W}\right)$. The climate is defined as temperate oceanic (Cfb in Köppen [35]). Summers are mild, with average maximum temperature of $20^{\circ} \mathrm{C}$ in July and August. Winters are cool with average minimum temperatures of $2{ }^{\circ} \mathrm{C}$. Like much of the British Isles, the relative humidity is high (69-88\% on average in a year). The simulations were run for the $21^{\text {st }}$ of June 2018 . Maximum air temperature was $21.2^{\circ} \mathrm{C}$ at 16:00 (British Summer Time: UTC+1), and minimum air temperatures was $14.8^{\circ} \mathrm{C}$ at 03:00. The simulations were run for 26 hours, starting from midnight [36]. Maximum UHI measured in Manchester was $2.3^{\circ} \mathrm{C}$ in 2018 [37].

\section{Results}

\subsection{Validation of the ENVI-met model}

Several studies have reported their validations for ENVI-met by comparing measured versus simulated results [38-42]. To validate the ENVI-met results of this study, measured and simulated air temperature datasets were compared. Figure 2-a shows the diurnal profile of ENVI-met simulated air temperatures vs measured data. This validation was done for the control scenario, which had no vegetation barrier in it (at receptor 1). The diurnal profile shows that increase and decrease of air temperatures for the two datasets occur at the same time of the day. Although the simulations were done with forced conditions, the simulated air temperatures are higher than measured data. The calculation of root mean square deviation (RMSD) was $1.6^{\circ} \mathrm{C}$ for the 24-hour data. Furthermore, Figure 2-b shows the scatter plot of the observed versus simulated air temperatures. The R square that shows how close the two data are to the fitted regression line is 0.91 . This shows how accurate ENVI-met was in predicting the air temperature.
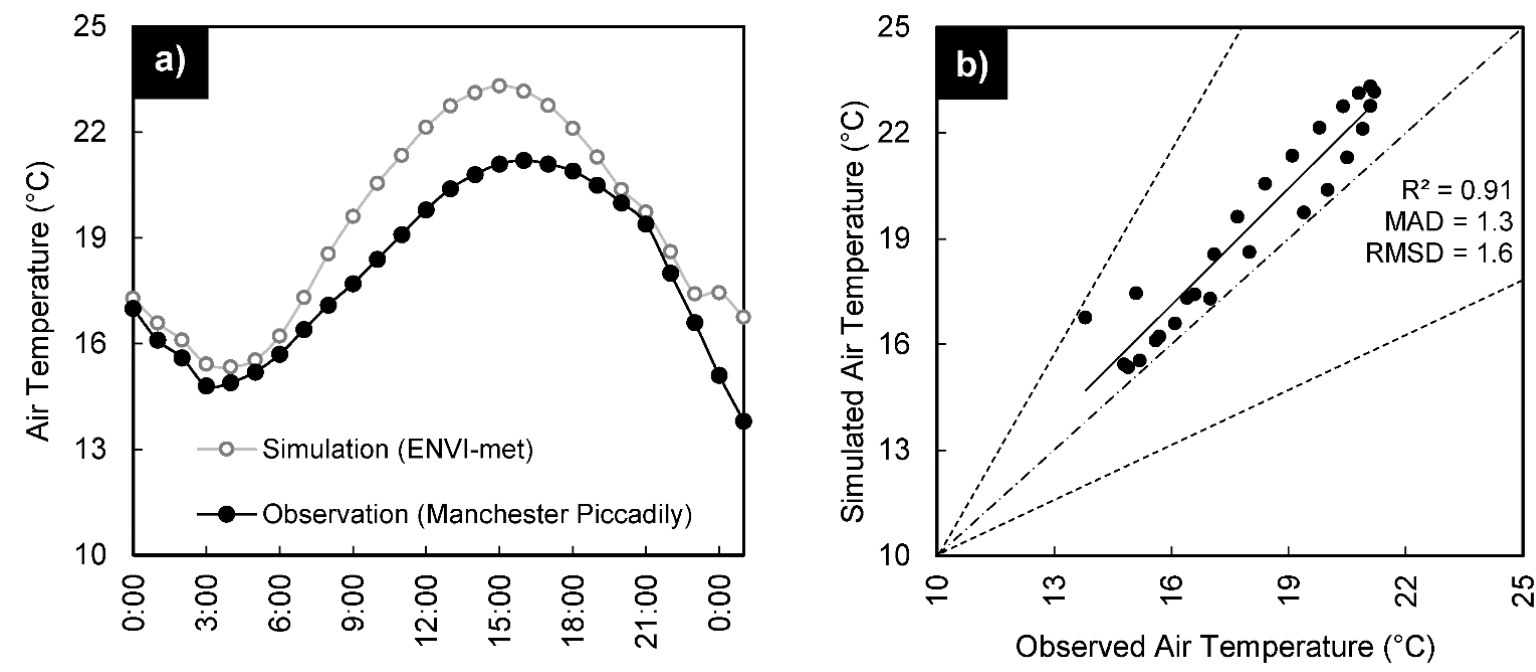

Figure 2: a) the diurnal profile of measured versus observed air temperatures; b) the scatter plot showing the regression between the two datasets. 


\subsection{Air pollution in Manchester (observations from Manchester Piccadilly Gardens)}

Figure 3-a shows the daily mean $\mathrm{NO}_{2}$ concentration data in 2018 measured by UK Air Information Resource [28]. The figure shows that $\mathrm{NO}_{2}$ concentration in colder months is higher than summer. The red dashed line shows $40 \mu \mathrm{g} / \mathrm{m}^{3}$ as the annual $\mathrm{NO}_{2}$ limit defined by the European Union legislation in the air quality directive (2008/EC/50) [43]. The annual mean in 2018 was $34.6 \mathrm{\mu g} / \mathrm{m}^{3}$ which is near the maximum threshold (daily data). The hourly mean concentration should not exceed $200 \mu \mathrm{g} / \mathrm{m}^{3}$ for 18 times in a year. Data show that maximum recorded $\mathrm{NO}_{2}$ concentration was $159.6 \mu \mathrm{g} / \mathrm{m}^{3}$ on $13^{\text {th }}$ of Feb at noon (Fig 3-b, hourly data) indicating that the limit value has not been exceeded. Figure 3-c shows the distribution of different classes of hourly $\mathrm{NO}_{2}$ concentration, with each class representing 5 $\mu \mathrm{g} / \mathrm{m}^{3}$. This figure is based on the hourly measured data. The maximum occurred class is the 25 to $30 \mu \mathrm{g} / \mathrm{m}^{3}$ with 1047 times frequency.

As discussed in the introduction, air pollution has an inverse relationship with air temperature. Mean monthly $\mathrm{NO}_{2}$ concentrations above $40 \mu \mathrm{g} / \mathrm{m}^{3}$ occurred in January, February and December with $40.9,44.3$, and $43.5 \mu \mathrm{g} / \mathrm{m}^{3}$, respectively. Minimum mean monthly $\mathrm{NO}_{2}$ concentration was $24.5 \mu \mathrm{g} / \mathrm{m}^{3}$ in July 2018. Note that minimum and maximum mean air temperatures in 2018 occurred in February and July with $1.6^{\circ} \mathrm{C}$ and $17.2^{\circ} \mathrm{C}$. 

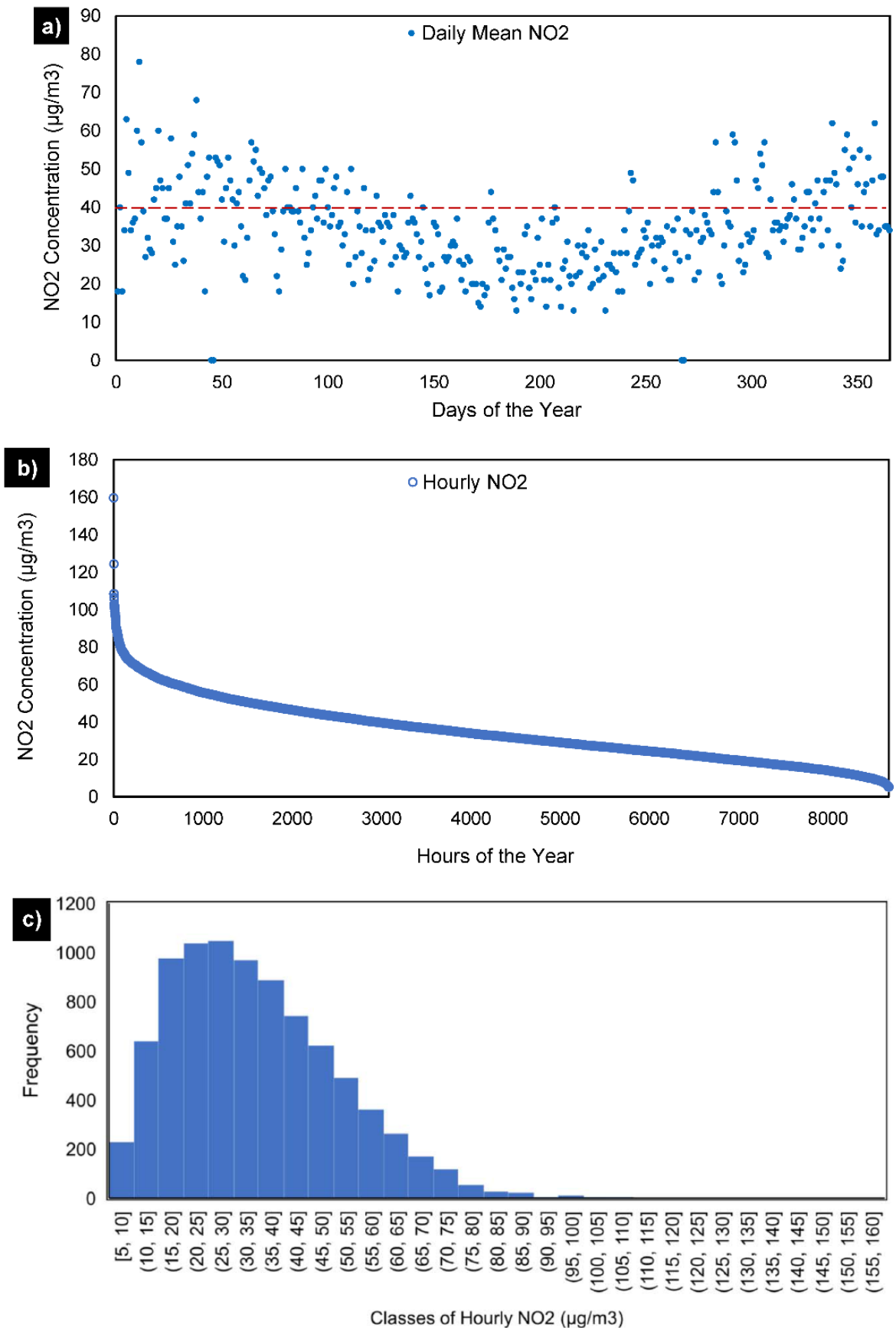

Figure 3: a) daily mean $\mathrm{NO}_{2}$ concentration in Manchester in 2018; b) hourly measured $\mathrm{NO}_{2}$ concentration arranged from the maximum to the minimum values; $c$ ) the histogram of hourly data.

\subsection{Concentration of $\mathrm{NO}_{2}$ in the control model}

Figure 4-a illustrates the hourly $\mathrm{NO}_{2}$ concentration and air temperature in receptor point 1 (R1) in the control model (with no green barrier) at $1.5 \mathrm{~m}$ height. It is shown that the air temperature and the $\mathrm{NO}_{2}$ concentration have an inverse relationship. After sunrise at 04:40, the air temperature increases, and it reaches to the maximum at $15: 00$ with $24.8^{\circ} \mathrm{C}$. Maximum $\mathrm{NO}_{2}$ concentration is $23.4 \mu \mathrm{g} / \mathrm{m}^{3}$ at 8:00. As the air temperature rises, the $\mathrm{NO}_{2}$ concentration decreases to the minimum $\left(18.4 \mu \mathrm{g} / \mathrm{m}^{3}\right)$ at 15:00. After 15:00, the air 
temperature decreases while the $\mathrm{NO}_{2}$ concentration increases. The correlation coefficient between the air temperature and $\mathrm{NO}_{2}$ concentration is -0.82 .

Figure 4-b shows the vertical distribution of $\mathrm{NO}_{2}$ concentration at $\mathrm{R} 1$ at 8:00 and 15:00 (when maximum and minimum concentrations of NO2 occurred, respectively). The two curves have their maximum differences $\left(6.1 \mu \mathrm{g} / \mathrm{m}^{3}\right)$ on the ground. By increasing of the height, the differences lead to zero. It is worth highlighting that at $10 \mathrm{~m}$ (the height of the building rooftops), the concentration is $0.1 \mu \mathrm{g} / \mathrm{m}^{3}$. Figure $4-c$ shows a similar vertical profile for the air temperature (at point R1). The air temperature curves at 8:00 and at 15:00 show reductions by the increase of the height. The rate of reduction in the air temperature curves led to zero at $10 \mathrm{~m}$ height, similar to the $\mathrm{NO}_{2}$ concertation curves.
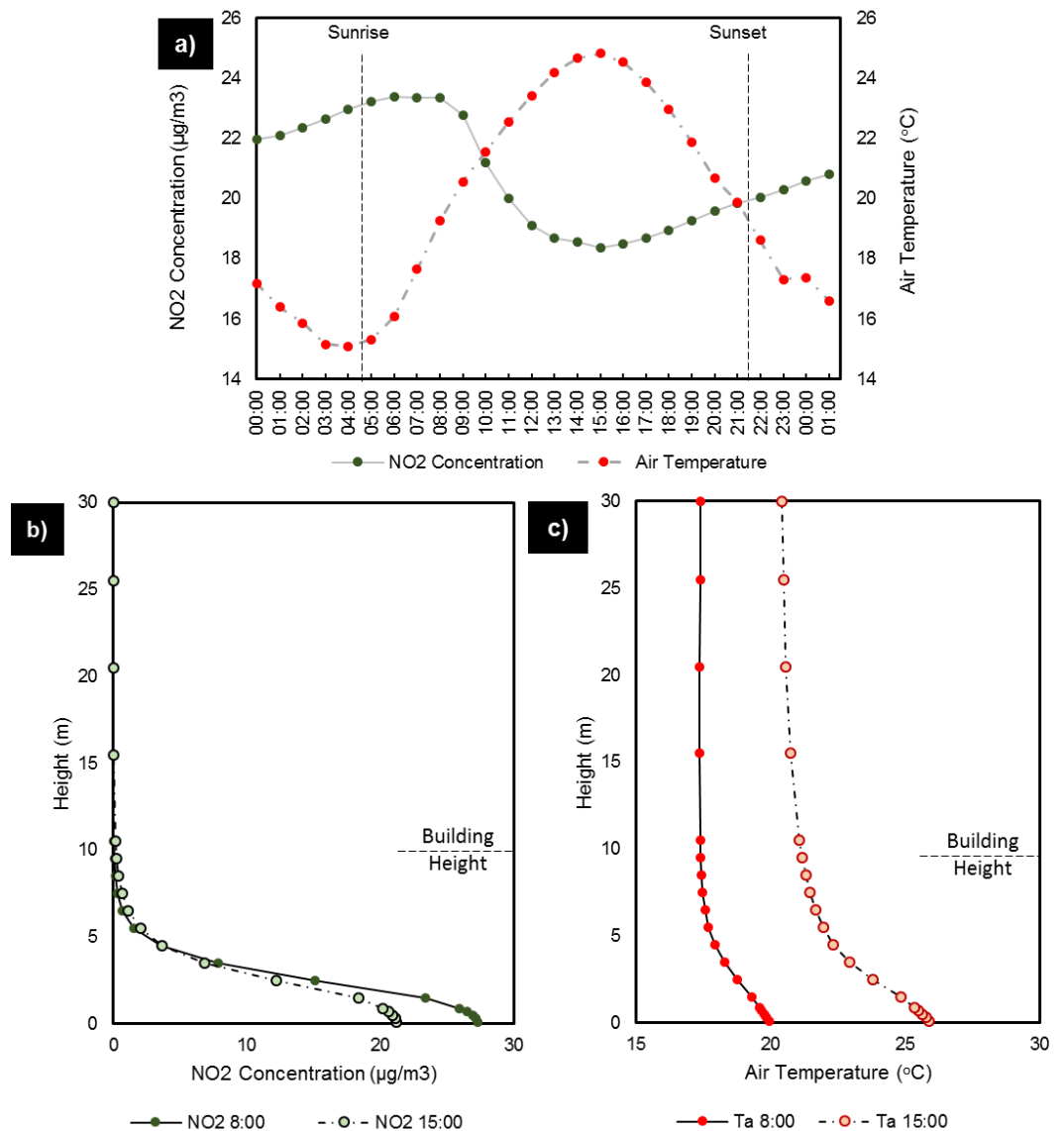

Fig 4: a) Diurnal profile of $\mathrm{NO}_{2}$ concentration versus air temperature in receptor 1 (R1) in the control model; b) vertical profiles of $\mathrm{NO}_{2}$ concentrations 8:00 and 15:00; and c) vertical profiles of air temperature at 8:00 and 15:00.

Top panels in Figure 5 show the $\mathrm{NO}_{2}$ concentration maps at 1.5m height at 8:00 and 15:00. Figure 5 bottom shows a cross section of the maps, comparing the concentrations at 8:00 and 15:00 vertically.

The $\mathrm{NO}_{2}$ concentration maps show that the concentration at 8:00 is higher than 15:00. The average concentration of $\mathrm{NO}_{2}$ within the whole neighbourhood is $6.0 \mu \mathrm{g} / \mathrm{m}^{3}$ at $8: 00$, and 4.7 $\mu \mathrm{g} / \mathrm{m}^{3}$ at 15:00 (the map and the values are for the height of $1.5 \mathrm{~m}$ ). As the distribution of 
$\mathrm{NO}_{2}$ is symmetrical in the domain at 8:00 and 15:00, a cross section is made to compare the $\mathrm{NO}_{2}$ concentration vertically.

The cross section shows a view from the middle of the domain to the east side. At 8:00, $\mathrm{NO}_{2}$ concentration near the ground level is higher than at 15:00. On the other hand, at 15:00, $\mathrm{NO}_{2}$ is dispersed to a higher level than at 8:00. This dispersion to a higher height can reduce the concentration at the ground level which is close to the pedestrian height. Maximum concentration of $\mathrm{NO}_{2}$ at 8:00 is $16 \mu \mathrm{g} / \mathrm{m}^{3}$, and at $15: 00$ is $11 \mu \mathrm{g} / \mathrm{m}^{3}$. Considering the fact that the emission rate is constant throughout the day, one reason for this concentration difference is the microclimatic differences. At 15:00, the ground surface and building envelopes have absorbed more solar radiation and are warmer than what they were at 8:00. The heated surfaces warm the ambient air. The neighbourhood is $5.1^{\circ} \mathrm{C}$ warmer at $15: 00$ compared to 8:00. The warmer air rises and can shift the pollution to a higher level. However, in cold periods the cold air sinks down, and the $\mathrm{NO}_{2}$ concentration is higher.

Note: Separate cross sections for the $\mathrm{NO}_{2}$ concentrations at 8:00 and 15:00 are provided in Appendix 2.
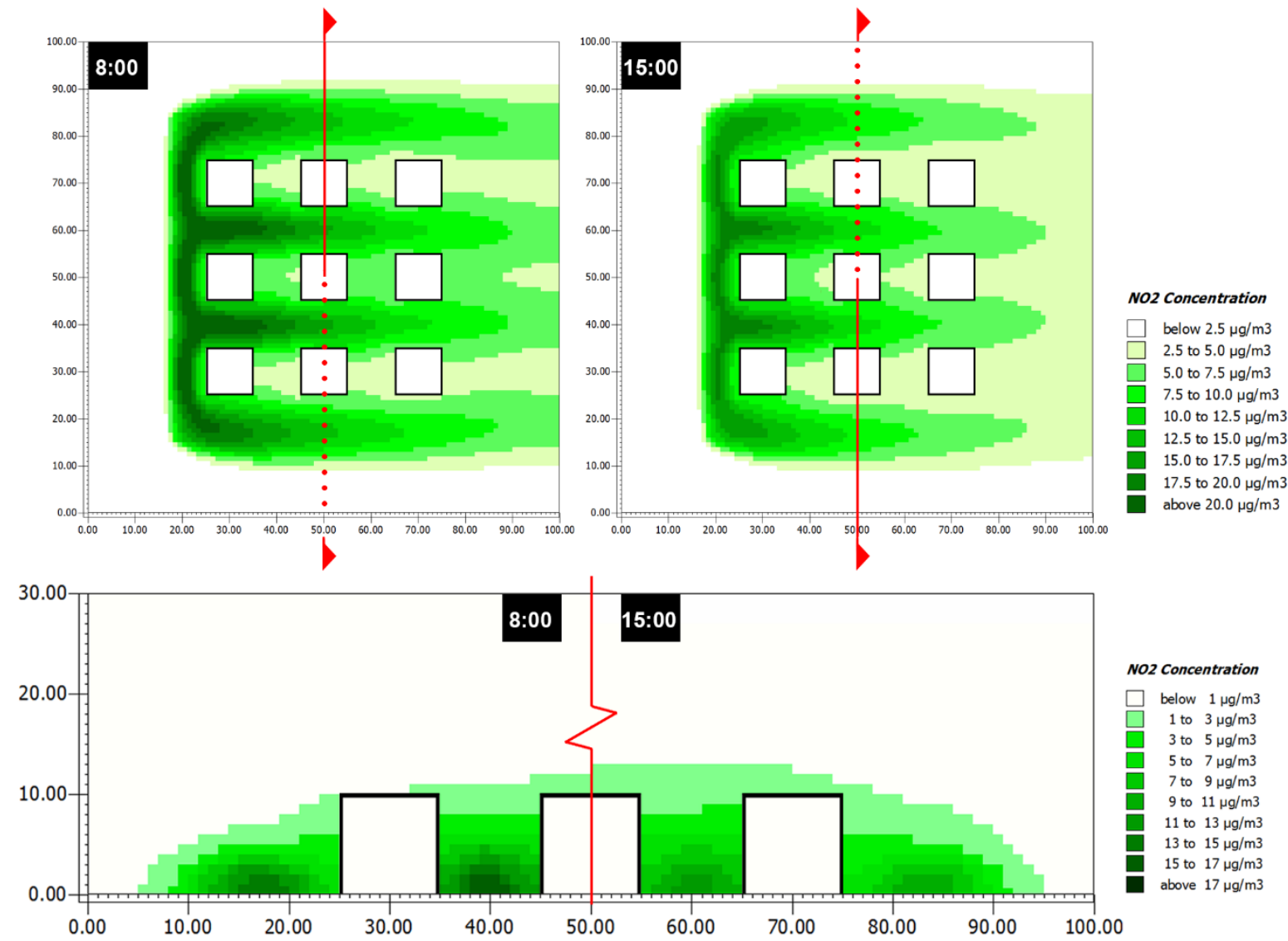

Fig 5: Top: the spatial distribution of $\mathrm{NO}_{2}$ at 8:00 and 15:00 at a height of $1.5 \mathrm{~m}$ in the Control model. Bottom: Two cross sections from 8:00 and 15:00 are put together to comparing the different concentration levels. 


\subsection{The impact of green barriers on the $\mathrm{NO}_{2}$ dispersion}

Figure 6-a shows the $\mathrm{NO}_{2}$ concentration in the five receptor points shown in Figure 1-b in the five different scenarios. The data are derived from 8:00, at a height of $1.5 \mathrm{~m}$. Receptor 1 (R1) is the closest point (distance of $10 \mathrm{~m}$ ) to the source of the pollution, and Receptor 5 (R5) is the farthest with the distance of $50 \mathrm{~m}$. The $\mathrm{NO}_{2}$ concentration reduces for all the scenarios from R1 to R5. Receptor points are shown in Figure 1-b.

At receptor 1 (R1) which is the closest point to the street, the minimum $\mathrm{NO}_{2}$ concentration occurs in the $\mathrm{T} 20$ scenario with $15.7 \mu \mathrm{g} / \mathrm{m}^{3}$. The Maximum concertation occurs in the $\mathrm{H} 4$ scenario with $23 \mu \mathrm{g} / \mathrm{m}^{3}$. The $\mathrm{H} 2$ and $\mathrm{H} 4$ scenarios that have introduced hedges to the neighbourhood show higher concentration of $\mathrm{NO}_{2}$ where these barriers are located.

By increasing the distance from the street (the pollution source), the $\mathrm{NO}_{2}$ concentration in $\mathrm{H} 2, \mathrm{H} 4$ and $\mathrm{T} 10$ are slightly higher than the control model. However, the $\mathrm{NO}_{2}$ concentration in the $\mathrm{T} 20$ scenario is $2.4 \mathrm{\mu g} / \mathrm{m}^{3}$ lower than the control model on average. The reduction rate (concentration values from R1 minus R5) for the control, H2, H4, T10, and T2O scenarios were $11.5,12.5,13.5,10.2$, and $7.1 \mu \mathrm{g} / \mathrm{m}^{3}$, respectively.

Figure 6-b shows the diurnal profile of $\mathrm{NO}_{2}$ change by implementing the different green scenarios. Maximum reductions occurred for the T20 scenario with an average of -5.1 $\mu \mathrm{g} / \mathrm{m}^{3}$. Trees with $10 \mathrm{~m}$ height also reduce the concentration slightly (with an average of -1.4 $\mu \mathrm{g} / \mathrm{m}^{3}$. Hedges ( $\mathrm{H} 2$ and $\mathrm{H} 4$ ) increased the concentration compared to the control model. The average increase was 1.3 and $2.2 \mu \mathrm{g} / \mathrm{m}^{3}$ for $\mathrm{H} 2$ and $\mathrm{H} 4$, respectively. It should be noted that the values are derived from receptor 1 (R1). The deviation of all scenarios from the control model is minimised by the increase of the temperature at 15:00.
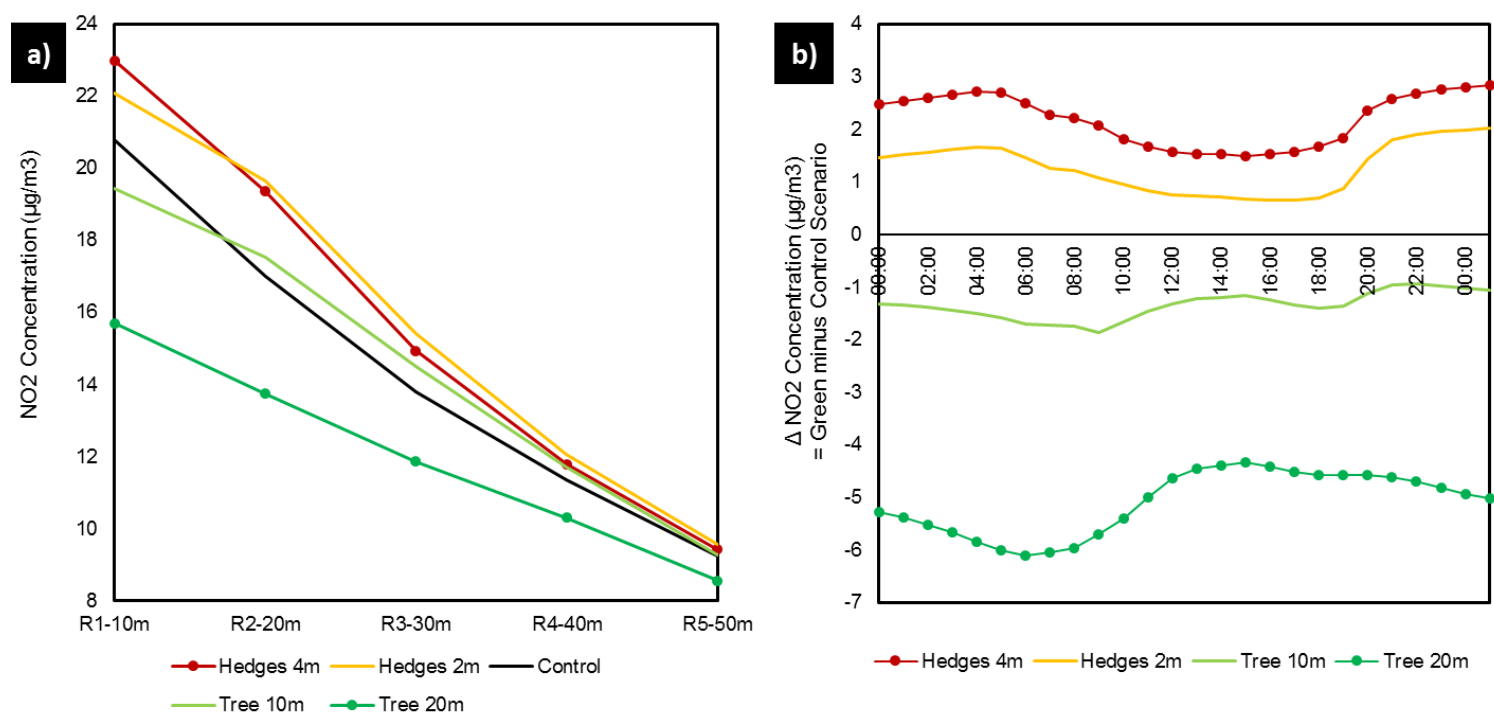

Fig 6: a) $\mathrm{NO}_{2}$ concentration at the receptor points in the five scenarios at 8:00; b) diurnal profile of $\mathrm{NO}_{2}$ concentration change $\left(\Delta \mathrm{NO}_{2}=\right.$ green minus control scenario $)$ at R1. Values for both graphs show data at a height of $1.5 \mathrm{~m}$. 
Figure 6 showed the neighbourhood response from a receptor point of view (R1). To understand the whole neighbourhood's response to the different scenarios, a spatial distribution of $\mathrm{NO}_{2}$ concentration is required. Figure 7 consists of different panels showing the micrometeorological variables in the green scenarios at $8: 00$ and at a height of $1.5 \mathrm{~m}$.

In Figure 7, panels a) to e) illustrate the $\mathrm{NO}_{2}$ concentrations in the neighbourhood under the different scenarios at 8:00. As previously discussed (and shown in Figure 6), the $\mathrm{NO}_{2}$ concentration in $\mathrm{H} 2$ and $\mathrm{H} 4$ are much higher than the control model. The panels show that the concentration is noticeable in the area between the street and the first column of the buildings (see panels $b$ ) and c)). Considering the whole neighbourhood, the T10 and T20 scenarios have much lower concentrations than $\mathrm{H} 2$ and $\mathrm{H} 4$. The maximum $\mathrm{NO}_{2}$ concentration in the whole neighbourhoods are $23.8,24.6,26.1,21.6$, and $17.7 \mu \mathrm{g} / \mathrm{m}^{3}$ for the control, $\mathrm{H} 2, \mathrm{H} 4, \mathrm{~T} 10$ and T20 scenarios, respectively.

In Figure 7, panels f) to i) show the concentration differences with the control model (=values from the green scenarios minus the control model). Reduction of $\mathrm{NO}_{2}$ is shown with blue, and the increase of the $\mathrm{NO}_{2}$ is shown with red colour. Comparing the green scenarios with the control model, the T20 scenario reduced the concentration by $0.3 \mu \mathrm{g} / \mathrm{m}^{3}$ on average in the whole neighbourhood.

Panels j) to $n$ ) in Figure 7 show the wind speed within the scenarios. Wind speed in the T20 and $\mathrm{T} 10$ scenarios are more than the $\mathrm{H} 2$ and $\mathrm{H} 4$ scenarios. Maximum wind speed occurred in the T20 scenario is $2.4 \mathrm{~m} / \mathrm{s}$, while it is 1.8 in the $\mathrm{H} 2$ scenario. This shows that wind can alter the $\mathrm{NO}_{2}$ concentration. The correlation coefficient between the maximum $\mathrm{NO}_{2}$ concentration and maximum wind speed is -0.88 . The negative value indicates the inverse relationship of pollution concentration with wind speed.

Note: see Appendix 3 for cross sections of $\mathrm{NO}_{2}$ concentration and wind speed in the different scenarios. 

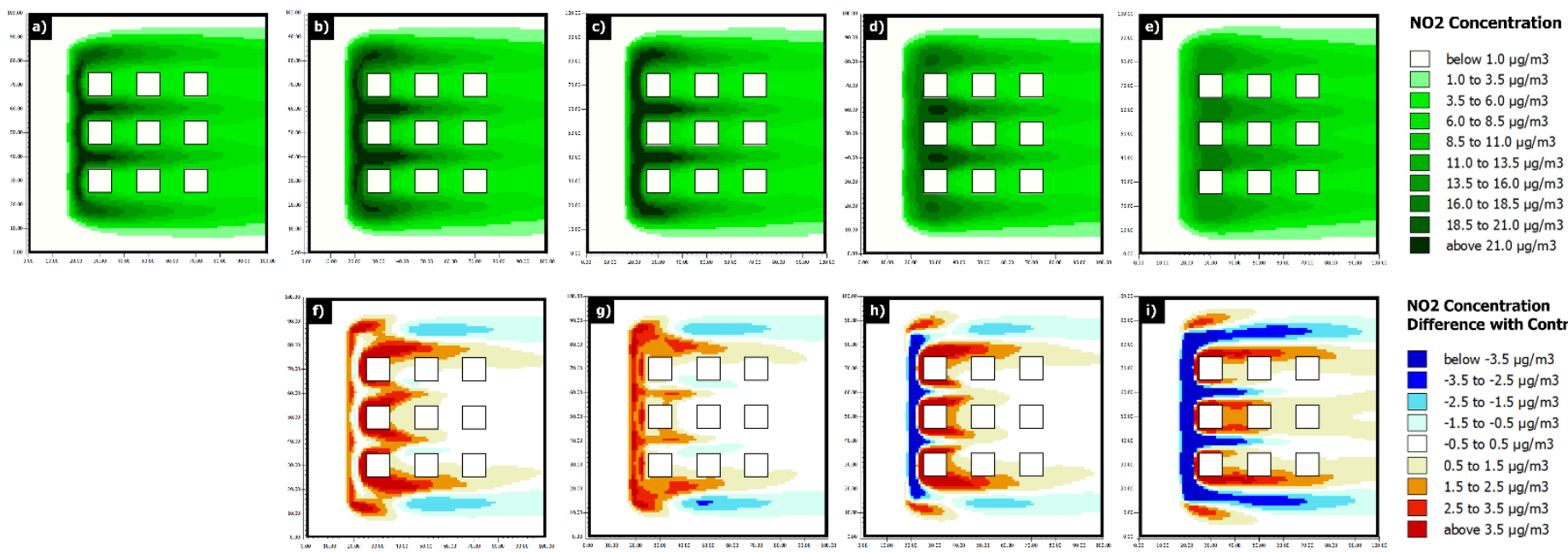

NO2 Concentration Difference with Contro

below $-3.5 \mu \mathrm{g} / \mathrm{m}$ -3.5 to $-2.5 \mu \mathrm{g} / \mathrm{m} 3$ -2.5 to $-1.5 \mu \mathrm{g} / \mathrm{m} 3$ -1.5 to $-0.5 \mu \mathrm{g} / \mathrm{m} 3$ -0.5 to $0.5 \mu \mathrm{g} / \mathrm{m} 3$ 0.5 to $1.5 \mathrm{\mu g} / \mathrm{m} 3$ 1.5 to $2.5 \mathrm{\mu g} / \mathrm{m} 3$ 2.5 to $3.5 \mu \mathrm{g} / \mathrm{m} 3$
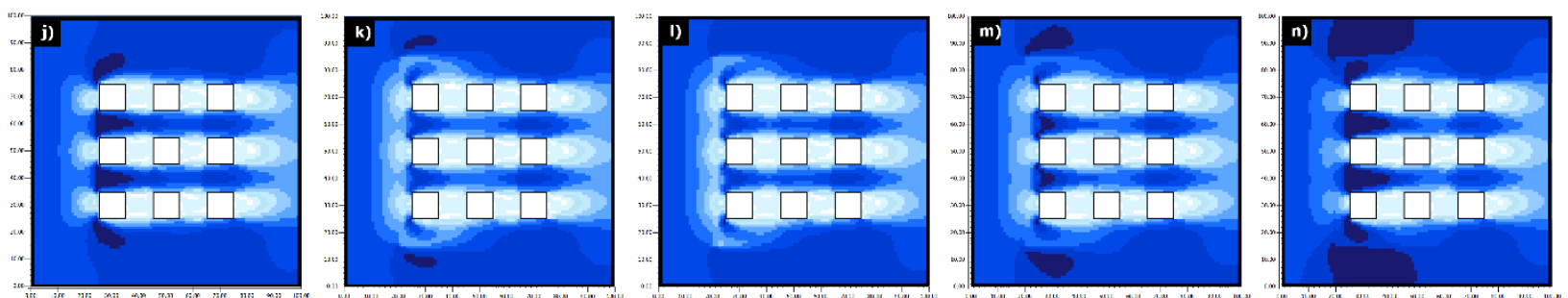

Fig 7: $\mathrm{NO}_{2}$ concentration (first row of panels), delta concentrations with the control model (second row of panels), and wind speed (third row of panels) in different scenarios at 8:00 at a height of $1.5 \mathrm{~m}$.

It is worth comparing the above results with the relevant studies on green barriers. Some studies $[44,45]$ showed that trees in urban canyons reduce the air movement, and this leads to a high concentration of air pollution. Others $[46,47]$ argued that low-level barriers like hedges could perform better by trapping the pollution between pedestrians and vehicles. There are also some studies [48-51] that confirm the ability of vegetation in removing pollution from highways for nearby residents. In this study, the investigated neighbourhood was not an exact urban canyon nor a highway like the abovementioned studies. Nevertheless, our results show that vegetation could increase (hedges scenarios) or decrease (trees scenarios) the pollution levels for pedestrians near and far from the source of pollution (i.e. the street). A main reason for that would be the physical shape of the green barriers. As Figure 1-a shows, hedges were modelled with full branches from the bottom to top; however, trees were bare in their lowest heights ( $1 \mathrm{~m}$ for T10, and $2 \mathrm{~m}$ for T20). As the height of the vehicle exhaust were $0.5 \mathrm{~m}$, the bare trunk of the trees facilitates the dispersion of the pollution coming from the street; however, hedges block the dispersion. Figure 10 (Appendix 3 ) illustrates the section of the neighbourhood with different scenarios. This Figure shows that the wind speed is higher in Tree scenarios than the Hedge scenarios. In general, the type of vegetation and the urban characteristics can improve (or deteriorate) air quality. 


\subsection{Caveats}

ENVI-met results presented in the validation (Section 3.1.) are from the weather station in Manchester Piccadilly Gardens. We used the weather data to run our hypothetical model. Ideally, validations should be performed for a real neighbourhood (i.e. for the neighbourhood that the measured data are taken from).

Regarding the pollution measurements in Manchester (Section 3.2.), we would like to highlight that the station is located in one of the busiest areas of Manchester. However, this point (and the results showed in the corresponding section) does not represent the whole city's air quality.

Furthermore, limit values for $\mathrm{NO}_{2}$ are set at two temporal scales - an annual limit value and an hourly limit value. There are areas in Manchester where monitoring and/or modelling demonstrates that the annual limit value is exceeded. In other words, there are areas in Manchester that exceed the annual mean and there will be times when the hourly mean is exceeded, but there is an allowable number of exceedances per year (18 times in a year).

\section{Conclusions}

Air pollution in UK is associated with thousands of deaths every year. This paper firstly looked at the $\mathrm{NO}_{2}$ concentrations in Manchester in 2018. Afterwards, the paper studied the impact of different green strategies (vegetated barriers) on $\mathrm{NO}_{2}$ mitigation in a hypothetical neighbourhood.

The study of the levels of $\mathrm{NO}_{2}$ in Manchester showed that the average annual concentration was $34.6 \mathrm{\mu g} / \mathrm{m}^{3}$ which was near the maximum threshold defined by the EU directives. Maximum observed $\mathrm{NO}_{2}$ was in February, and in general, higher concentrations occurred in cold months. This finding could be useful for policy makers to provide assistance for vulnerable groups, such as people with asthma or COPD.

Diurnal analysis of $\mathrm{NO}_{2}$ concentration in the control scenario showed that the minimum concentration occurs during the hottest hours of the day. This behaviour is similar to the pollution levels in a larger scale in Manchester, and in general in urban scale.

By implementing different green barriers between the source of the pollution (street) and the buildings, it was observed that hedges increase the pollution level near the street (at the pedestrian level). This was due to the reduced wind speed while using the hedges as green barriers. Using the trees, however, facilitated the dispersion of pollution as the lowest part of the trees were bare (trunk with no branches). This study showed that the selection of green strategies to reduce air pollution in a neighbourhood highly depends on the circulation of air in urban canyons. The correlation coefficient between the $\mathrm{NO}_{2}$ concentration and maximum windspeed in the different scenarios was -0.88 . This finding could be useful for cities with tight urban canyons. Furthermore, the use of vegetation should not block the circulation of air in urban canyons. 
The modelling in this paper suggests that green infrastructure does have a role to play in better managing air quality in the urban built environment. However, it does identify that this must be carefully designed; a universal "green is good" policy might lead to a lack of consideration as to the impact of design choices that have the potential to exacerbate, rather than improve, the problem of pollution in some cases. Further research might consider addressing the differing performance of plant types within the model, such a deciduous as opposed to coniferous plants. Furthermore, as this study was done for a summer day, the study of winter condition for both deciduous and coniferous plants would show their effectiveness in long term. There is also potential for a validation exercise to be undertaken within a demonstrator site to consider the performance of the model against measured data, which would address the main limitation of this research.

\section{Appendix 1:}
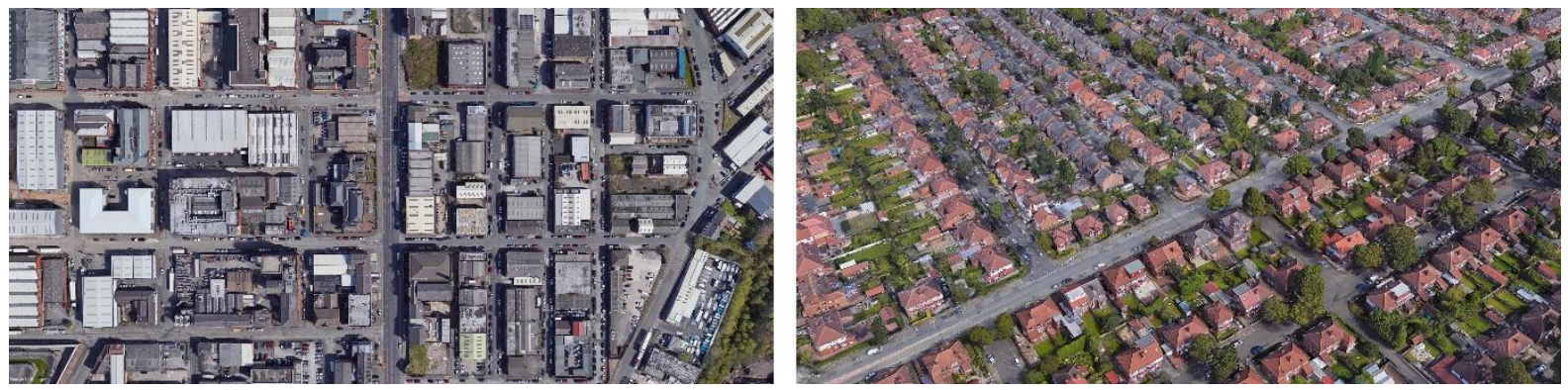

Figure 8: The grid street plan in the north side of Manchester (left); and residential grid blocks in Old Trafford, south of Manchester (right). Images are from Google Earth Pro.

\section{Appendix 2:}
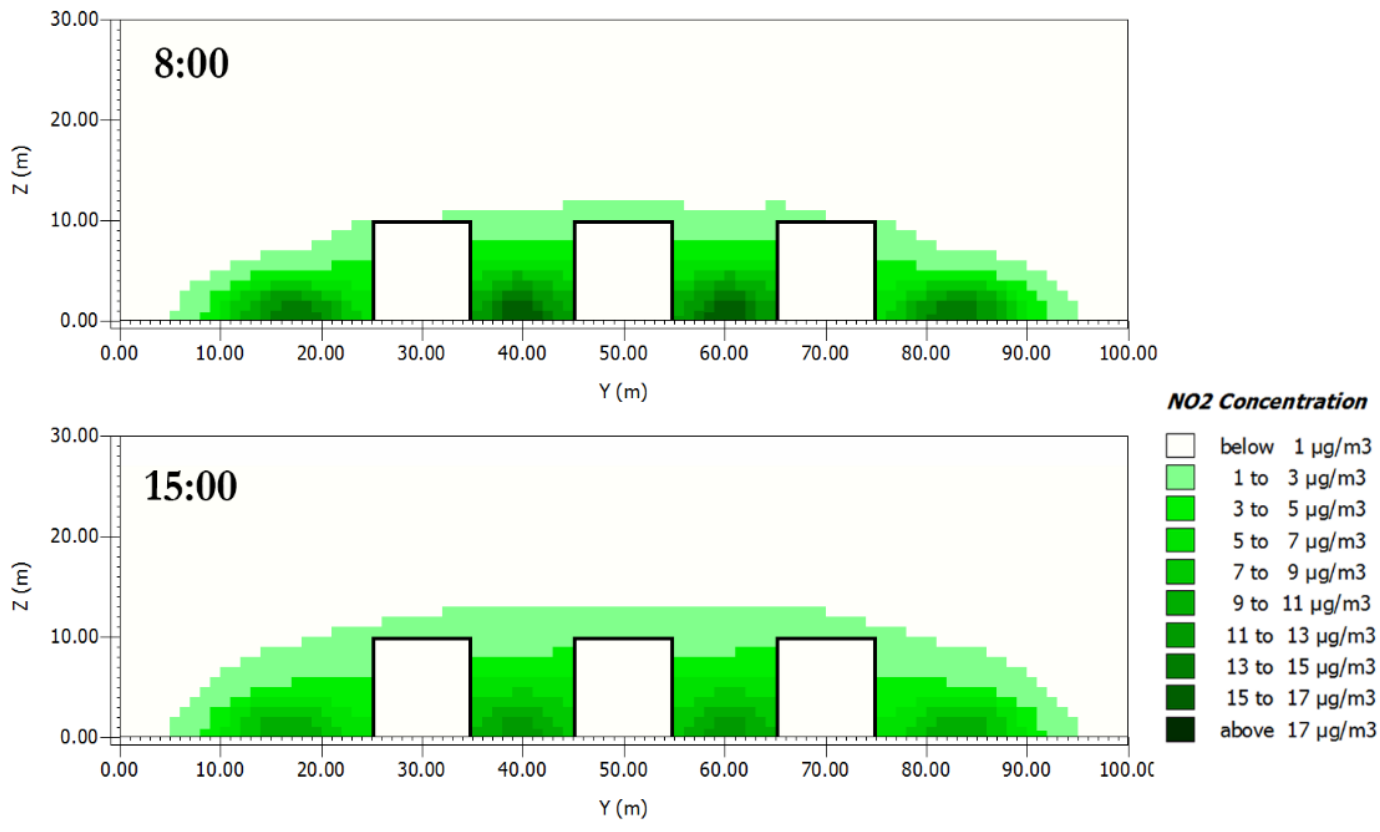

Figure 9: $\mathrm{NO}_{2}$ concentrations in the Control model at 8:00 and 15:00. 


\section{Appendix 3:}

\section{Control}
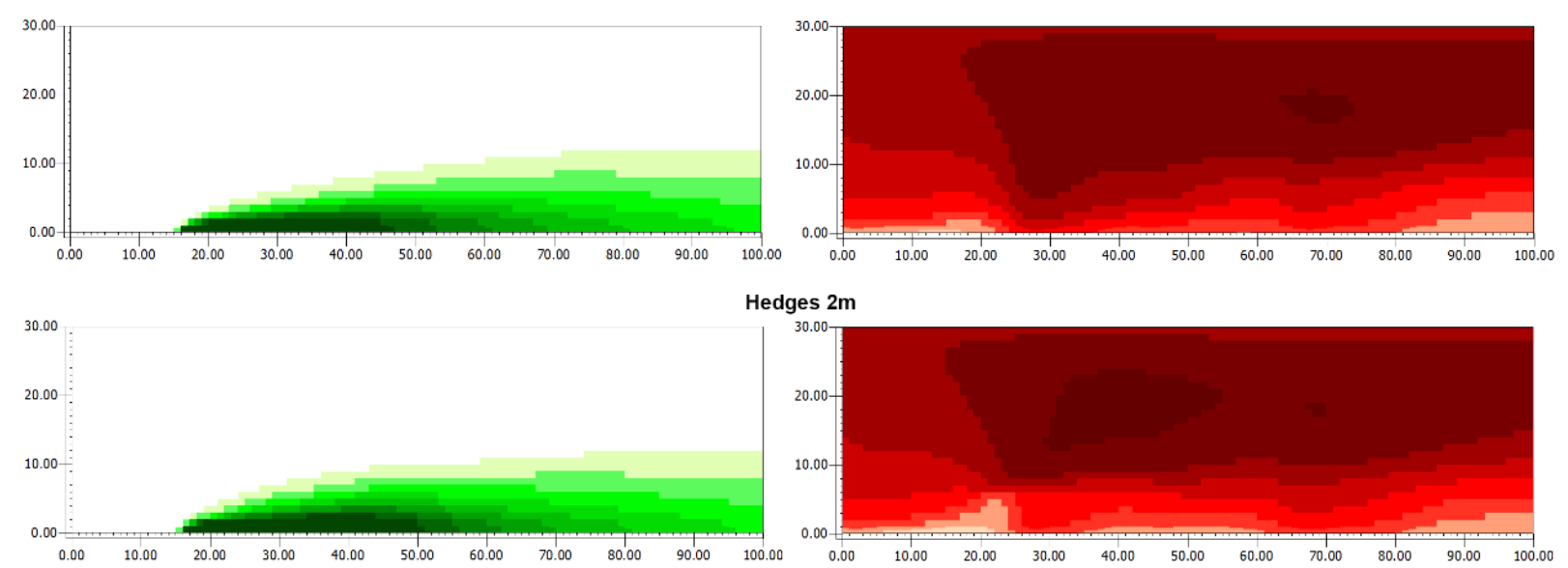

Hedges $2 \mathrm{~m}$
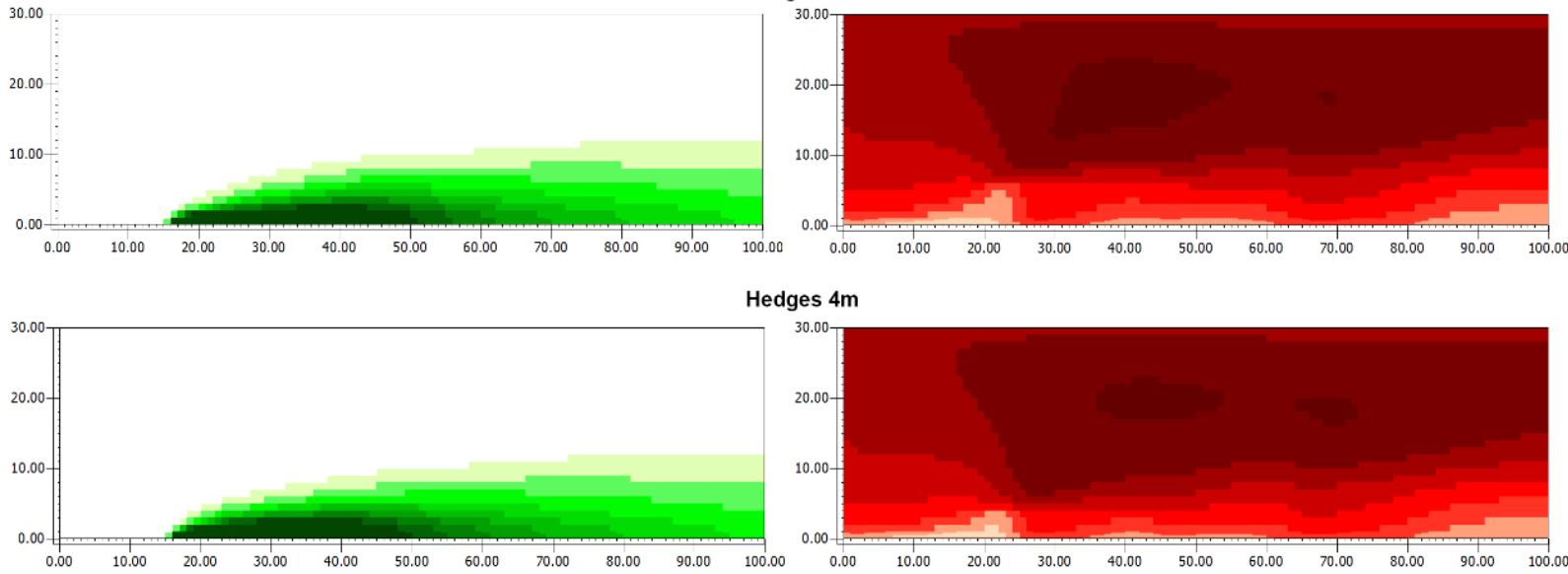

Hedges $4 \mathrm{~m}$

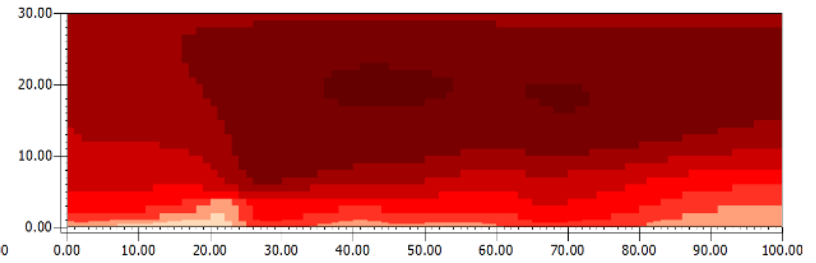

Trees $10 \mathrm{~m}$

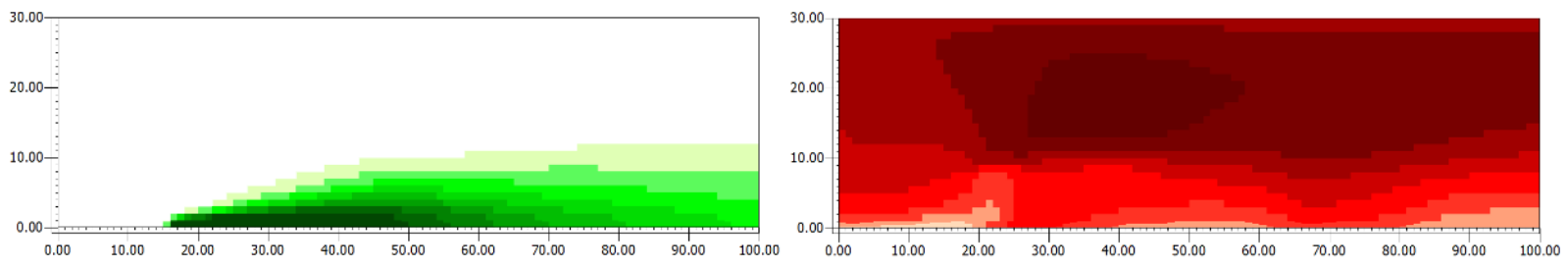

Trees 20m
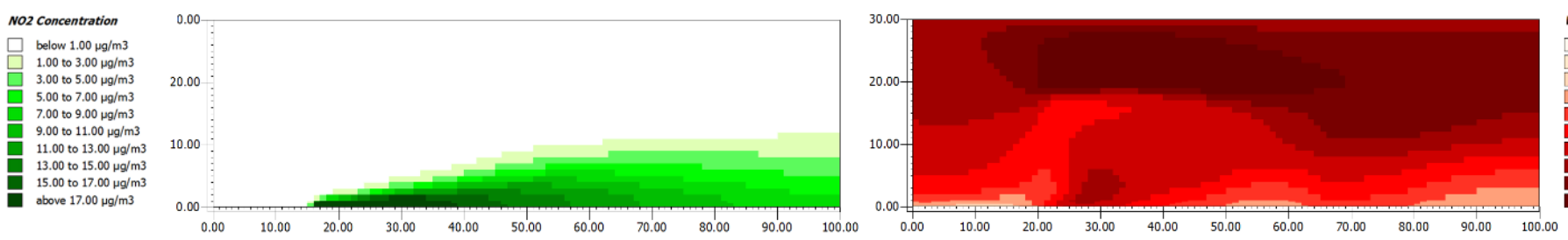

Wind Speed

below $0.30 \mathrm{~m} / \mathrm{s}$

0.60 to $0.90 \mathrm{~m} / \mathrm{s}$

0.90 to $1.20 \mathrm{~m} / \mathrm{s}$

1.20 to $1.50 \mathrm{~m} / \mathrm{s}$

1.50 to $1.80 \mathrm{~m} / \mathrm{s}$
1.80 to $2.10 \mathrm{~m} / \mathrm{s}$

2.10 to $2.40 \mathrm{~m} / \mathrm{s}$

2.40 to $2.70 \mathrm{~m} / \mathrm{s}$

$0.00 \quad 10.00$

Figure 10: Cross sections (east-west of the neighbourhood) of $\mathrm{NO}_{2}$ concentration and wind speed in the scenarios at 8:00.

\section{References:}

1. Bell Michelle, L., L. Davis Devra, and T. Fletcher, A retrospective assessment of mortality from the London smog episode of 1952: the role of influenza and pollution. Environmental Health Perspectives, 2004. 112(1): p. 6-8.

2. Clean Air Act 1956, in http://www.legis/ation.gov.uk/ukpga/1956/52/pdfs/ukpga 19560052 en.pdf. UKGovernment: Retrieved 29.03.2019.

3. Air Pollutant Inventories for England, Scotland, Wales, and Northern Ireland: 1990-2016, in https://uk- 
air.defra.gov.uk/assets/documents/reports/cat09/1810160958 DA Air Pollutant Inventorie s 1990-2016 Issue1.pdf. 2016, National Atmospheric Emissions Inventory, Department for Environment Food \& Rural Affairs: Retrieved 29.03.2019.

4. COMEAP, The Mortality Effects of Long-Term Exposure to Particulate Air Pollution in the United Kingdom, in https://assets.publishing.service.gov.uk/government/uploads/system/uploads/attachment data/file/304641/COMEAP mortality effects of long term exposure.pdf. 2018, Committee on the Medical Effects of Air Pollutants: Accessed 20.03.2019.

5. RCP, Every breath we take: the lifelong impact of air pollution, in https://www.rcplondon.ac.uk/projects/outputs/every-breath-we-take-lifelong-impact-airpollution. 2016, Royal College of Physicians: Accessed 09.05.2019.

6. Achakulwisut, P., et al., Global, national, and urban burdens of paediatric asthma incidence attributable to ambient NO2 pollution: estimates from global datasets. The Lancet Planetary Health, 2019. 3(4): p. e166-e178.

7. EEA, Nitrogen dioxide-Annual limit values for the protection of human health, in https://www.eea.europa.eu/data-and-maps/figures/nitrogen-dioxide-annual-limit-valuesfor-the-protection-of-human-health. 2014, European Environment Agency: Accessed 11.02.2019.

8. Chang, E. and V.J. Terwilliger, The effects of air pollution on vegetation from a geographic perspective. Progress in Physical Geography: Earth and Environment, 2000. 24(1): p. 53-74.

9. Samuel, N., Effects of Air Pollutants on Vegetation, in Introduction to the Scientific Study of Atmospheric Pollution, B.M. McCormac, Editor. 1971, Springer Netherlands: Dordrecht. p. 131-151.

10. Locosselli, G.M., et al., The role of air pollution and climate on the growth of urban trees. Science of The Total Environment, 2019. 666: p. 652-661.

11. Taha, H., Meteorological, air-quality, and emission-equivalence impacts of urban heat island control in California. Sustainable Cities and Society, 2015. 19: p. 207-221.

12. Taha, H., Cool Cities: Counteracting Potential Climate Change and its Health Impacts. Current Climate Change Reports, 2015. 1(3): p. 163-175.

13. Li, Y., et al., Effects of urbanization on regional meteorology and air quality in Southern California. Atmos. Chem. Phys., 2019. 19(7): p. 4439-4457.

14. Akbari, H., M. Pomerantz, and H. Taha, Cool surfaces and shade trees to reduce energy use and improve air quality in urban areas. Solar Energy, 2001. 70(3): p. 295-310.

15. Fu, X., et al., Effects of canyon geometry on the distribution of traffic-related air pollution in a large urban area: Implications of a multi-canyon air pollution dispersion model. Atmospheric Environment, 2017. 165: p. 111-121.

16. Oke, T.R., et al., Urban Climates. 2017, Cambridge: Cambridge University Press.

17. Oke, T.R., Boundary Layer Climates. 2002, London: Taylor \& Francis.

18. Qiu, H., et al., Season and humidity dependence of the effects of air pollution on COPD hospitalizations in Hong Kong. Atmospheric Environment, 2013. 76: p. 74-80.

19. Guo, Y., et al., The association between air pollution and mortality in Thailand. Scientific Reports, 2014. 4: p. 5509.

20. Moya, T.A., et al., A review of green systems within the indoor environment. Indoor and Built Environment, 2018. 28(3): p. 298-309.

21. Janhäll, S., Review on urban vegetation and particle air pollution-Deposition and dispersion. Atmospheric Environment, 2015. 105: p. 130-137.

22. Shi, Y., et al., Investigating the influence of urban land use and landscape pattern on PM2.5 spatial variation using mobile monitoring and WUDAPT. Landscape and Urban Planning, 2019. 189: p. 15-26. 
23. Abhijith, K.V., et al., Air pollution abatement performances of green infrastructure in open road and built-up street canyon environments - A review. Atmospheric Environment, 2017. 162: p. 71-86.

24. Abbass, O.A., D.J. Sailor, and E.T. Gall, Effectiveness of indoor plants for passive removal of indoor ozone. Building and Environment, 2017. 119: p. 62-70.

25. Ramasubramanian, P., et al., Pilot study on the impact of green roofs on ozone levels near building ventilation air supply. Building and Environment, 2019. 151: p. 43-53.

26. Ozdemir, H., Mitigation impact of roadside trees on fine particle pollution. Science of The Total Environment, 2019. 659: p. 1176-1185.

27. de Hoogh, K., et al., Spatial PM2.5, NO2, O3 and BC models for Western Europe - Evaluation of spatiotemporal stability. Environment International, 2018. 120: p. 81-92.

28. UK-Air. Air Information Resource. Accessed 17.09.2018 2018 [cited 2018; Available from: https://uk-air.defra.gov.uk/.

29. Bruse, M. ENVI-met website. Accessed 27.02.2019 2019; Available from: http://www.envimet.com.

30. Middel, A., N. Chhetri, and R. Quay, Urban forestry and cool roofs: Assessment of heat mitigation strategies in Phoenix residential neighborhoods. Urban Forestry \& Urban Greening, 2015. 14(1): p. 178-186.

31. Taleghani, M., Dwelling on Courtyards: Exploring the energy efficiency and comfort potential of courtyards for dwellings in the Netherlands. 2014, Delft University of Technology.

32. Taleghani, M., et al., The impact of heat mitigation strategies on the energy balance of a neighborhood in Los Angeles. Solar Energy, 2019. 177: p. 604-611.

33. Kleerekoper, L., et al., Urban measures for hot weather conditions in a temperate climate condition: A review study. Renewable and Sustainable Energy Reviews, 2017. 75: p. 515-533.

34. Bruse, M. ENVI-met implementation of the gas/ particle dispersion and deposition model PDDM. Accessed 27.03.2019 2007; Available from: http://envimet.net/documents/sources.PDF.

35. Kottek, M., et al., World Map of the Köppen-Geiger climate classification updated. Meteorologische Zeitschrift, 2006. 15(3): p. 259-263.

36. Climate \& Weather Averages in Manchester. [cited 2019 14.02.2019]; Available from: https://www.timeanddate.com/weather/uk/manchester/climate.

37. Taleghani, M., et al., Renaturing a microclimate: The impact of greening a neighbourhood on indoor thermal comfort during a heatwave in Manchester, UK. Solar Energy, 2019. 182: p. 245-255.

38. Morakinyo, T.E., et al., Thermal benefits of vertical greening in a high-density city: Case study of Hong Kong. Urban Forestry \& Urban Greening, 2019. 37: p. 42-55.

39. Dhariwal, J., et al., Evaluating the effectiveness of outdoor evaporative cooling in a hot, arid climate. Building and Environment, 2019. 150: p. 281-288.

40. Taleghani, M., The impact of increasing urban surface albedo on outdoor summer thermal comfort within a university campus. Urban Climate, 2018. 24: p. 175-184.

41. Nasrollahi, N., et al., Numerical evaluation of thermal comfort in traditional courtyards to develop new microclimate design in a hot and dry climate. Sustainable Cities and Society, 2017. 35: p. 449-467.

42. Nasrollahi, N., Z. Hatami, and M. Taleghani, Development of outdoor thermal comfort model for tourists in urban historical areas; A case study in Isfahan. Building and Environment, 2017. 125: p. 356-372.

43. Directive 2008/50/EC of the European Parliament and of the Council of 21 May 2008 on ambient air quality and cleaner air for Europe. 2019, Official Journal of the European Union. p. 1-44. 
44. Jeanjean, A.P.R., et al., Air quality affected by trees in real street canyons: The case of Marylebone neighbourhood in central London. Urban Forestry \& Urban Greening, 2017. 22:

p. 41-53.

45. Buccolieri, R., et al., The impact of trees on street ventilation, NOx and PM2.5 concentrations across heights in Marylebone Rd street canyon, central London. Sustainable Cities and Society, 2018. 41: p. 227-241.

46. Abhijith, K.V. and P. Kumar, Field investigations for evaluating green infrastructure effects on air quality in open-road conditions. Atmospheric Environment, 2019. 201: p. 132-147.

47. Deshmukh, P., et al., The effects of roadside vegetation characteristics on local, near-road air quality. Air Quality, Atmosphere \& Health, 2019. 12(3): p. 259-270.

48. Eisenman, T.S., et al., Urban trees, air quality, and asthma: An interdisciplinary review. Landscape and Urban Planning, 2019. 187: p. 47-59.

49. Brantley, H.L., et al., Field assessment of the effects of roadside vegetation on near-road black carbon and particulate matter. Science of The Total Environment, 2014. 468-469: p. 120-129.

50. Xing, Y. and P. Brimblecombe, Role of vegetation in deposition and dispersion of air pollution in urban parks. Atmospheric Environment, 2019. 201: p. 73-83.

51. Nowak, D.J., et al., Air pollution removal by urban forests in Canada and its effect on air quality and human health. Urban Forestry \& Urban Greening, 2018. 29: p. 40-48. 